\title{
Perkembangan Kognitif Anak Usia Dini Penyandang Disleksia: Studi Kasus Pada Lembaga Pendidikan Di Indonesia
}

\author{
Lilif Muallifatul Khorida Filasofa \\ PIAUD, Fakultas Ilmu Tarbiyah dan Keguruan, UIN Walisongo Semarang \\ liliffilasofa@walisongo.ac.id \\ Miswati \\ PIAUD, Fakultas Ilmu Tarbiyah dan Keguruan, UIN Walisongo Semarang \\ miswati03860@gmail.com
}

\begin{abstract}
Dyslexia is a disorder of the nervous system that is characterized by difficulty recognizing words both reading, spelling, understanding symbols and distinguishing letters. Dyslexic children experience barriers to cognitive development. Children tend to be slow in thinking and hard to understand things like counting, analyzing and understanding words. Some factors that cause children to experience dyslexia are educational, psychological and biological factors. But the main thing is neubiological factors or the brain. This is due to poor connectivity in the function of parts of the brain, namely the brocas, frontal lobe and cortex. Therefore parents or teachers need to implement appropriate strategies or handling methods so that the child's cognitive abilities can develop properly.
\end{abstract}

Keywords : Cognitive ; Dyslexia; Methods; Child; 


\section{ABSTRAK}

Disleksia adalah gangguan pada sistem sarafyang ditandai dengan kesulitan mengenali kata- kata baik membaca, mengeja, memahami simbol serta membedakan huruf. Anak disleksia mengalami hambatan pada perkembangan kognitifnya. Anak cenderung lambat dalam berfikir dan susah memahami sesuatu seperti menghitung, menganalisa serta memahamikata. Penelitian menggunakan penelitian kualitatif dengan metode studi kasus. Beberapa faktor yang menyebabkan anak mengalami disleksia adalah faktor pendidikan, psikologis dan biologis. Namun yang paling utama adalah faktor neubiologis atau pada otak. Hal ini disebabkan adanya konektivitas yang buruk dalam fungsi bagian otak, yaitu pada daerah brocas, lobus frontal dan korteks. Maka dari itu orang tua maupun guru perlu menerapkan strategi atau metode penanganan yang tepat agar kemampuan kognitif anak dapat berkembang dengan baik.

Kata kunci : Kognitif; Disleksia; Metode; Anak; 
55 Lilif Muallifatul Khorida Filasofa and Miswati

\section{PENDAHULUAN}

Membaca adalah bagian dari kegiatan belajar. Menurut Subini , membaca adalah dasar utama untuk memperoleh kemampuan belajar berbagai bidang. Sedangkan menurut Farida Rahim, membaca adalah sesuatu yang melibatkan banyak hal, tidak sekedar melafalkan tulisan, namun melibatkan aktivitas visual dan berfikir(Ozila Sandriani, Ganda Sumekar, 2013). Dari berbagai pandangan, dapat disimpulkan bahwa membaca adalah suatu aktivitas belajar yang melibatkan kemampuan berfikir dalam melafalkan kata dengan tujuan untuk untuk memperoleh kemampuan belajar berbagai bidang. Namun, sebagian anak- anak beranggapan bahwa membaca tidak semudah yang dibayangkan. Banyak anak- anak yang mengalami gangguan dalam belajar seperti kesulitan dalam membaca, mengeja huruf atau memahami arti kata. Gangguan belajar seperti ini sering disebut disleksia (Irdamurni, Kasiyatil, Zulmiyetri, 2018).

Penanganan terhadap anak yang mempunyai gejala disleksia harus mendapat perhatian khusus(Sri Respati Andamari, 2017). Penanganan yang sesuai dan tepat dapat membantu dalam proses belajar ditingkat selanjutnya. Hal ini dikarenakan anak yang tidak dibimbing secara khusus akan berdampak pada perkembangan kognitif selanjutnya.Perkembangan kognitif pada anak tentunya sangat tergantung dengan proses kegiatan belajarnya, termasuk dalam menganalisa dan berfikir. Dalam meningkatkan perkembangan kognitifnya maka diperlukan stimulus- stimulus yang khusus untuk melatihnya. Terutama pada anak yang mengalami gangguan disleksia. Hal ini dikarenakan pemberian stimulus yang sesuai dengan tahapan perkembangan anak akan menghasilkan hasil yang maksimal.

Pemberian stimulus yang sesuai tidak terlepas dari metode pengajaran yang di lakukan oleh guru maupun orang tua. Metode pengajaran yang dimaksud adalah strategi yang digunakan guru maupun orang tua untuk meningkatkan kemampuan kognitif anak disleksia. Strategi yang tepat dapat dilakukan oleh guru sebagai pembimbing, fasilitator dan pemberi informasi. Sehingga mampu untuk meminimalisir kekurangan anak disleksia serta meningkatkan keterampilan membaca anak. Maka dari itu perlunya peningkatan kemampuan kognitif pada anak disleksia agar tahapan perkembangan kognitifnya dapat berkembang sesuai tahapan usianya. 


\section{METODE PENELITIAN}

TK Bunga Harapan yang dijadikan obyek penelitian studi kasus di Jl. Kompleks Masjid Baitul Istighfar Bringin Ngaliyan. TK Bunga Harapan didirikan pada tahun 2009 dibawah naungan yayasan Jawor. Jenis Penelitian yang dipakai adalah penelitian kualitatif dengan metode studi kasus. Studi kasus yaitu jenis penelitian kualitatif yang mempunyai fungsi untuk menyelidiki proses, mendapatkan informasi dan memperoleh informasi yang mendalam. Sedangkan kasus yang diteliti adalah perkembangan kemampuan kognitif anak disleksia. Data di dapatkan dari hasil pengamatan terhadap anak dan melakukan interview dengan orang tua dan pendidik.

\section{HASIL DAN PEMBAHASAN}

1. Pengertian Disleksia

Kata disleksia berasal dari bahasa Yunani yaitu"dys" berarti kesulitan dan "lexis" berati kata- kata. Dalam arti sempitnya disleksia berarti kesulitan dalam membaca. Sedangkan dalam arti luasnya, disleksia yaitu segala bentuk kesulitan yang berhubungan dengan katakata , misalnya kesulitan membaca, memahami kata- kata , mengeja, dan membedakan huruf(Tri Wulan Sari, Anna Vitara, 2015). Menurut Pelaksana Harian Asosiasi Disleksia Indonesia dr. Kristiantini, Sp.A., disleksia adalah kelainan pada dasar neurobiologis dan ditandai dengan kesulitan mengenali kata dengan tepat dalam pengejaan serta mengode simbol. Adapaun menurut Asosiasi Disleksia Internasional menjelaskan bahwa : "The International Dyslexia Association (2002) defines dyslexia as a specific learning disability of neurological origin. It is characterized by accuracy and fluency difficulties in recognizing written words, and problems in decoding and spelling. These difficulties are caused by a deficit in the phonological component of language, unexpected in nature, since other cognitive skills have normal development and education is appropriate".

Asosiasi Disleksia Internasional (2002) mendefinisikan disleksia sebagai ketidakmampuan belajar khusus neurologis asal. Hal ini ditandai dengan kesulitan keakuratan dan kefasihan dalam mengenali kata-kata tertulis, dan masalah dalam decoding dan ejaan. Kesulitankesulitan ini disebabkan oleh defisit komponen fonologis bahasa, yang tidak terduga sifatnya, karena keterampilan kognitif lain memiliki perkembangan normal dan pendidikan yang sesuai(León, Bravo, \& Fernández, 2017). 
Dari beberapa pengertian diatas, disleksia adalah suatu kelainan yang ditandai dengan kesulitan mengenali kata- kata baik membaca, memahami simbol serta membedakan huruf sehingga menghambat perkembangan kognitif pada anak yang disebabkan karena ada kelainan dalam neurobiologis. Hal ini tidak terlepas dari teori perkembangan kognitif oleh Jean Piaget yang mengarah pada kemampuan berfikir,memproses dan menilai sebelum melakukan tindakan. Tindakan tersebut selalu melibatkan pemikiran, pengetahuan dan kreativitas dalam pembelajaran(Ubaidullah \& Zaman, 2011).

2. Jenis- Jenis Disleksia

Ada tiga tipe dasar disleksia yaitu : disleksia disponesia, disleksia disnemkinesia dan disleksia diseldesia. Disleksia ini bisa di artikan sebagai jenis disleksia dimana anak tersebut sulit untuk membedakan bunyi dan mengenal betul bunyi yang ada di dalam perkataan dan menggabungkan bunyi tersebut dalam suku kalimat. Disleksia disponesia disebut juga audiotory/ fonologikal. Masalah utamaya adalah terletak pada penyatuan huruf dan bunyi. Anak yang mengalami disleksia ini sulit mengenali bunyi fonetik huruf atau kata- kata. Jadi , anak disleksia disponesia ini merasa bingung dengan bunyi huruf yang didengar. Misalnya ketika ada yang mengucapkan kata "buku" anak bisa saja beranggapan "kubu", sehingga anak ini tidak bisa menyatukan anatara bunyi dan huruf.

Disleksia disnemkinesia atau disleksia developmental. Masalah utamanya adalah daya ingat dan pergerakan motorik yang menyebabkan anak tersebut membalik- balikan huruf di dalam kalimat. Buruknya pengembangan kemampuan visual spesial membuat anak kesulitan mengenali huruf p,q,b,d. Kemudian anak akan sulit untuk membuat kata dan membangun kosakata. Sehingga anak akan sangat pelan- pelan dalam membacanya. Dari penjelasan tersebut, yang perlu digaris bawahi adalah daya ingat anak lemah dan sering membolak balikan huruf. Misalnya saja ada kata " budi” tetapi anak menulis atau membacanya "idub" atau "dibu".

Disleksia diseldesia atau disleksia visual yaitu penderita disleksia ini dapat melihat dengan baik namun tidak dapat membedakan, mengingat perkataan, bentuk gambar,dan angka. Ciricirinya misalkan sulit mebedakan perkataan atau huruf yang hmapir sama, misalnya bas- pas, ubi- ibu. Dan terkadang juga sering menyebut kata dengan terbalik seperti sapu- supa), lalu tidak memiliki keinginan 
untuk kegiatan olahraga(Inkofar, 2017). Disleksia diseldesia atau disleksia visual adalah sulit membaca kata atau kalimat dan menguraikan kata- kata secara keseluruhan, sehingga kalimat yang dibacanya tidak beraturan. Selain itu anak ini susah untuk menerima informasi secara berurutan. Pada penderita disleksia visual memiliki ingatan jangka pendek dan penglihatan berurutan(Hermijanto \& Valentina, 2016). Dari penjelasan tersebut, anak sulit membaca satu kalimat utuh. Membacanya juga tidak bisa runtut mulai dari kata pertama, kedua, dan seterusnya. Ingatan jangka pendeknya membuat anak tersebut susah mengenali kata atau informasi yang berurutan.

3. Karakteristik Disleksia

Dalam Diagnostic and Statistical Manual of Mental Disorder IVdisleksia memilki karakteristik sebagai berikut:

a. Prestasi dalam membaca terukur secara individual dari ketepatan serta pemahaman dalam membaca. Hal ini dapat diketahui adanya kesalahan dalam membaca (distorsion), penggantian huruf atau kata dalam membaca (substutions), dan penghilangan huruf (omissions). Selain itu kecepatan dalam membaca sangat lambat serta pemahaman yang kurang tepat.

b. Jika terdapat gangguna penglihatan, dampaknya akan kesulitan membaca.

c. Gangguan prestasi membaca berpengaruh terhadap prestasi akademik atau kegiatan yang berkaitan dengan membaca.

Menurut Reynolds, dkk , ciri anak yang mengalami disleksia yaitu kelemahan dalam menggunakan simbol atau kode dalam mengeja sebagaimana mestinya. Kemudian keterbatasan dalam ingatan jangka pendek. Serta kelemahan dalam menulis seperti kesulitan dalam menerima informasi untuk belajar.(Varia Nihayatus Saadah, 2013)

Sedangkan menurut Subini,ciri - ciri disleksia adalah sebagai berikut:

a. Lambat dalam membaca kata demi kata dibandingkan anak seusianya. Intonasi suara juga naik turun tidak beraturan.

b. Tidak dapat mengucapkan iram kata dengan benar .

c. Sering terbalik dalam mengenali huruf dan kata, misalnya kata lupa $><$ palu, kuda $><$ daku. Huruf "b" dibaca "p" atau "q" dibaca "P".

d. Sulit memahami kata- kata yang mirip, misalnya rusa dengan lusa, baru dengan batu,dan lain- lain.

e. Sering mengulangi dan menebak kata- kata.

f. Kesulitan memahami isi teks dibacanya. 
g. Kesulitan mengurutkan huruf dalam kata.

h. Kesulitan menyuarakan fonem (satuan bunyi) dan memadukan menjadi kata.

i. Kesulitan mengeja secara baik dan benar.

j. Membaca satu kata benar di satu halaman, tapi salah membaca di halaman lainya.

k. Sering terbalik dalam menulis kalimat, misalnya " tukang kayu membuat patung" menjadi " tukang patung membuat kayu”.

l. Lupa meletakkan tanda titik dan tanda baca yang lainya(Pratiwi, Hapsari, \& Argo, 2015).

Ciri - ciri diatas adalah karakteristik yang terjadi pada anak disleksia pada umumnya. Antara anak disleksia satu dengan lainya belum tentu mengalami ciri- ciri yang sama. Sehingga dapat katakan bahwa karakter anak disleksia tergantung dari masing - masing anaknya. Tetapi ciri dasar pada umumnya anak disleksia kesulitan dalam memahami sesuatu yang berkaitan dengan membaca.

4. Penyebab Disleksia

Penyebab disleksia adalah gangguan pada daya ingat serta pemrosesan dalam fungsi otak. Penelitian psikolog klinis dari Universitas Katolik Leuven, Belgia, Bart Boets menyatakan interkoneksi otak anak disleksia terutama dibagian otak yang namanya Broca, yaitu lobus frontal otak yang mengolahpengucapan dan dibagian kortek kiri dan kanan.Dikarenakan koneksi yang lemah maka membuat kemampuan membaca dan berbicaranya menjadi buruk.Tentunya hal ini jika dibiarkan secara terus- menerus akan berakhibat fatal bagi perkembangan anak(Olivia, 2014).
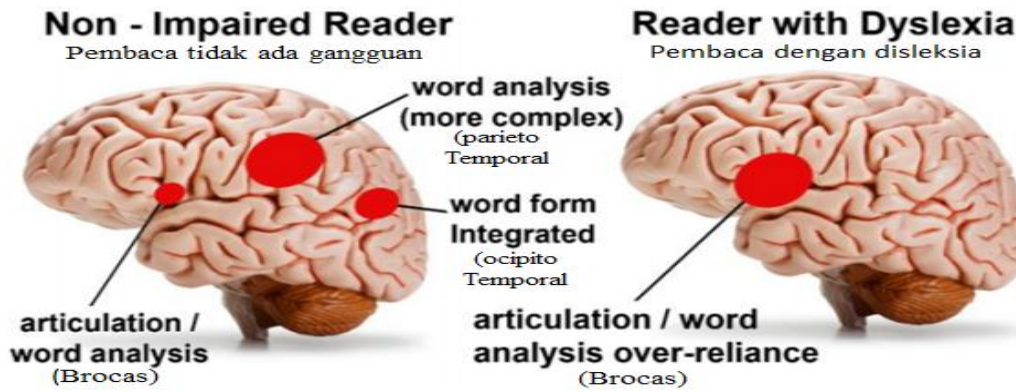

Pembaca dengan disleksia

articulation / word analysis over-reliance (Brocas)

Gambar : Otak orang normal dan otak penderita disleksia 
Pada gambar diatas sebelah kiri adalah otak normal (nonimpaired reader) untuk analisis kata dan pengucapan artikulasi berada di daerah brocas, kemudian untuk analisis kata yang lebih kompleks berada pada bagian parieto temporal. Lalu untuk kata dari terintegrasi berada pada bagian ocipito tempral. Masing- masing kegiatan berada pada bagian otak yang berbeda- beda. Namun pada penderita disleksia baik untuk kegiatan pengucapan artikulasi , analisis kata tergantung pada satu bagian saja yaitu di brocas. Sehingga penderita disleksia mengalami koneksi yang tidak baik dalam membaca serta memahami kata.

Kemudian ada peneliti tentang otak normal dan otak penderita disleksia. Anak yang mengalami disleksia mengalami konektivitas yang buruk, yaitu pada daerah brocas, lobus frontal dan korteks .

Terdapat penelitian lagi, bahwa terdapat perbedaan antara otak anak normal dan otak anak disleksia, yaitu bagian temporo - parietaloksiitalnya(otak bagian samping dan belakang). Dilakukan pemeriksaan functional Magnetic Resonancy Imaging untuk mengetahui aktivitas membaca Ternyata aktivitas otak anak disleksia dengan anak normal jauh berbeda dalam memproses kata yang dibaca.

Menurut Dardjowidjojo faktor penyebab disleksia ada tiga, yaitu faktor pendidikan, psikologis, dan biologis. Tetapi faktor yang paling utama adalah otak.

a) Faktor pendidikan

Disleksia dapat disebabkan karena metode yang digunakan menggunakan metode " whole - word" yaitu mengajarkan kata- kata sebagai kesatuan dari pada mengajarkan kata sebagai bentuk bunyi tulisan. Alangkah lebih baik anak diajarkan dengan metode fonetik ini mengajarkan anak tentang nama- nama huruf berdasarkan bunyinya. Anak yang belajar menggunakan metode fonetik lebih mudah mempelajari kata- kata baru. Dengan demikian penggunaan kedua metode ini. Selain mengenali kata sebagai satu kesatuan unit, anakpun akan belajar cara menerapkan aturan metode fonetik pada kata- kata yang baru.

Jadi, pendidikan orang tua bisa menjadi penyebab anak disleksia. Ketika pola asuh orang tua yang salah, tentunya akan berdampak pada anak. Kebanyakan orang tua memaksa anak untuk belajar secara terus menerus hingga anak jenuh dan lelah. Orang tua sangat berambisi agar anaknya menjadi peringkat satu di kelas. Tetapi orang tua tersebut salah memberikan metode pengajaran dalam pola asuhnya. Misalnya 
saja anak dari pagi sampai siang belajar di sekolahan. Setelah pulang dari sekolahan anak di suruh untuk mengulang lagi pelajaran di sekolah. Malamnya anak diminta belajar lagi untuk keesokan harinya. Hal ini menjadi beban bagi anak. Terdapat tekanan dalam proses belajar. Sehingga anak bukan menjadi mudah paham justru susah untuk memahami materi.

b) Faktor Psikologis

Penelitian menyebutkan, anak disleksia mengalami gangguan emosional dikarenakan kurang disiplin, sering pindah sekolah, pola asuh orang tua dan lain- lain. Sehingga anak merasa tidak nyaman dengan kondisi tersebut. Hal ini akan sangat berpengaruh terhadap kemampuan kognitifnya. Anak akan malas untuk mempelajari hal- hal yang berkaitan dengan akademik seperti mrmbaca, menulis, berhitung, dan melakukan analisis lainya. Anak disleksia merasa tidak menyukai kondisi apapun. Tidak ada yang mendukung dirinya dalam melakukan suatu hal. Serta banyak yang tidak suka dengan kondisinya saat ini. Sehingga anak disleksia banyak di jauhi teman- temannya karena dianggap aneh.

c) Faktor Biologis

Ada penelitian bahwa anak disleksia ada gangguan dari fungsi bagian otak. Hal ini menyebabkan perkembangan berfikirnya lebih lambat. Namun ada juga yang berpendapat faktor genetik juga bisa menyebabkan anak disleksia. Dari penelitian menyatakan bahwa anak disleksia berasal dari orang tua yang disleksia atau gangguna lainya. Pengaruh gen dari orangtua memang susah untuk dicegah. Namun seiring dengan perkembangannya serta penanganan yang tepat, anak disleksia akan menjadi anak yang luarbiasa. Disisi lain dalam pendekatan teori deficit fonologi, bahwa anak disleksia mempunyai kelemahan dalam fonologinya. Dalam penelitian oleh pakar neuropsycological menyebutkan bahwa anak disleksia bersumber dari fonologidan kelemahan dalam kognitifnya yaitu masalah membaca dan menulis. Akibatnya ada keterbatasan dalam memori verbalnya, kesulitan memberi nama, kemampuan mengulang yang rendah(Hidayah, 2013).

Secara garis besar faktor penyebab anak disleksia adalah ada gangguan dalam perkembangan kognitifnya. Adapaun teori perkembangan kognitif menurut Jean Piaget, bahwa tahapan perkembangan setiap orang dan usia sangat mempengaruhi kemampuan seseorang dalam ilmu pengetahuan. Menurutnya, struktur 
dari perkembangan kognititf bahwa anak sudah mengetahui dunia sekitarnya. Hal ini dikarenakan pengalaman anak dan lingkungan sekitar dapat mengubah perkembangan anak. Sehiingga pertumbuhan kecerdasan intelektual akan terus berkembang. Adapun tahapan teori perkembangan kognitif menurut Jean Piaget yaitu:

a. Tahap Sensorimotorik (0-2 tahun)

Pada tahapan ini dunia anak sedang belajar tentang diri mereka sendiri melalui pancaindera yang sedang berkembang melalui aktivitas sehari- hari. Sehingga semua berpusat pada sensori dan motoriknya, artinya anak mampu mengenal lingkungannya melalui inderanya. Hal tersebut menjadi sesuatu yang paling dasar untuk pengembangan kognitif selanjutnya.

b. Tahap Pra-operasional (2-7 tahun)

Pada tahapan ini anak menunjukan kegiatan kognitifnya dalam berbagai hal diluar dirinya. Anak sudah mampu memahami lingkungan sekitarnya dengan menggunakan simbol- simbol. Cara berfikir anak pada tahap ini tidak konsisten dan tidak logis yang ditandai dengan: transductiv reasoning (berfikir tidak logis), tidak jelas hubungan sebab- akibat, animisme (meyakini benda itu hidup seperti dirinya), artificialism, (meyakini benda dilingkungan itu mempunyai jiwa), perceptually bound (menilai sesuatu dari apa yang didengar atau diihat), mental experiment (mencoba sesuatu dan menemukan jawaban dari apa yang dihadapinya dan centration (memusatkan sesuatu yang menarik dan mengabaikan yang lainya).

c. Tahap Operasional Konkrit (7- 12 tahun)

Pada tahapan ini anak sudah bisa secara logika namun belum begitu matang dan hanya objek yang ada saat ini. Sebagai contoh, ada tiga boneka A,B,C mempunyai warna rambut berbeda, ada kuning, cokelat, dan hitam. Anak tidak kesulitan berfikir rambut yang paling gelap . tetapi jika rambut A lebih terang dari B dan rambut B lebih terang dari $\mathrm{C}$, anak akan kesulitan menjawabnya. Hal ini dikarenakan anak belum mampu berfikir menggunakan lambang- lambang.

d. Tahap Operasional Formal (12 tahun keatas)

Pada tahapan ini anak sudah bisa berfikir operasi konkrit yang lebih kompleks. Anak pada tahapan ini sudah bisa berfikir secara abstrak dan mampu memahami bentuk argumen dan memahami sesuatu walaupun bentuknnya tidak ada(Ibda, 2015). 
5. Penanganan Dalam Peningkatan Kemampuan Kognitif Anak Disleksia

Dileksia ini tidak bisa disembuhkan tetapi hanya bisa membaik. Maka dari itu perlunya deteksi sejak dini serta penanganan yang lebih baik akanmemberikan hasil yang maksimal. Namun jika tidak cepat ditangani berakibat pada gangguan sosial dan emosional. Gangguan ini berdampak pada sikapnya menjadi kurang percaya diri, mudah tersinggung, mudah marah, serta merasa dirinya tidak bisa apa- apa bahkan menjadi korban bullying teman- temannya. Selain berdampak pada sosial emosionalnya, gangguan ini sangat berdampak pada perkemabangan kognitif selanjutnya. Kemampuan kognitif anak akan tertinggal jauh daripada teman- teman seusianya. Anak yang mengalami disleksia dapat dideteksi mulai usia 3-4 tahun melalui tanda- tanda sebagai berikut: suka mencampur kata, sulit mengulang bunyi dan irama, sulit mengingat nama atau obyek, perkembangan bahasanya lambat dan sulit untuk berpakaian.

Ketika anak sudah didiagnosa mengidap disleksia, orang tua segera untuk mengonsultasikan ke psikolog, klinik atau pengajaran khusus. Tujuannya agar anak mendapat penangann khusus serta membantu meningkatkan perkembangan kognitifnya. Maka peran orang tua serta gurunya sangat berpengaruh penting dalam hidupnya. Anak harus mendapat dukungan ekstra baik secara psikis maupun secara fisiknya. Orang tua mempunyai kewajiban untuk mendidiknya, baik ketika di rumah maupun memantau anak saat disekolahan, sehingga orang tua tidak memasrahkan begitu saja kepada pihak guru maupun pihak sekolah. Hal ini sangat berpengaruh terhadap perkembangan kognitif anak disleksia. Anak disleksia bukan berati anak tersebut selamanya tidak bisa membaca dan menulis. Jika anak tersebut mendapat penanganan yang tepat, anak disleksia mampu untuk membaca dan menulis layaknya anak normal lainya. Maka dari itu orang tua harus mengenali sejak dini perkembangan anaknya. Sehingga jika anak sudah menunjukan gejalanya, orang tua mampu melakukan tindakan intervensi selanjutnya(Lidwina, 2012).

Orang tua selalu aktif dalam mendampingi anak dari waktukewaktu. Orang tua harus memahami kesulitan anak disleksia dalam belajar. Pola asuh yang digunakan orang tua harus tepat sesuai dengan kondisi anak. Orang tua yang sangat otoriter selalu menginginkan anaknya mendapat nilai yang sempurna, terutama dalam hal sains , 
sementara anak yang mengalami disleksia mengalami kekurangan dalam kemampuan kognitifnya. Selalu memberikan dorongan untuk mengembalikan kepercayaan diri anak disleksia. Anak disleksia cenderung akan menghabiskan waktunya untuk menguasai materi pelajaran seperti membaca, menulis, dan berhitung. Anak akan berusaha dengan caranya sendiri. Sehingga perlunya mempertahankan kepercayaan diri pada anak agar dirinya terus mencoba memecahkan masalah itu. Orang tua harus selalu menduku apa yang dilakukan anak. Orang tua tidak boleh membatasi gerak anak dan bersikap otoriter. Jika anak selalu ditekan dan dibatasi ruang geraknya, anak sulit untuk berkembang. Sehingga ini berdampak pada tingkat kepercayaan dirinya. Misalnya saja anak membuat gambar dengan imajinasinya. Gambarnya biasa saja bahkan tidak rapi. Kemudian orang tua tidak mendukung gambar tersebut. Orang tua justru bilang apa adanya bahwa gambar tersebut kurang bagus. Maka anak tersebut akah berkurang kepercayaan dirinya. Bahkan anak tidak akan menggambar lagi.

Ketika mengajari anak disleksia pembelajaran harus dibuat semenarik mungkin. Anak disleksia kebanyakan tidak suka membaca. Orang tua atau guru harus kreatif untuk menciptakan suasana belajar yang menyenangkan. Jangan pernah memarahi atau membentak ketika anak tidak paham-paham apa yang dijelaskan. Bisa jadi metode penyampaiannya kurang menarik. Orang tua terus memberi semangat dengan memberikan contoh orang- orang sukses pengidap disleksia. Anak disleksia pasti mempunyai tokoh- tokoh yang disukai atau menggemari tokoh. Berikan contoh tokoh pengidap disleksia yang sudah sukses. Misal anak suka dengan tokoh Albert Einstein, orang tua memberi gambaran bahwa Albert Einstein ini sulit memahami bacaan tetapi dia mampu menjadi orang paling pintar. Dengan begitu anak akan merasa sangat antusias dan semangat. Bantu mengembangkan berfikirnya dengan teknologi yang mendukung imajinasinya. Anak disleksia sangat menyukai hal - hal yang berkaitan dengan bendabenda luar angkasa. Berikan anak software atau permainan tentang planet- planet atau benda- benda luar angkasa yang didalamnya terdapat pembelajaran kognitifnya. Misal permainan untuk mengurutkan nama- nama planet dan lain sebagainya. Selain itu anak akan berusaha berimajinasi, sehingga membantu anak dalam mengembangkan daya fikirnya(Tammasse, 2017). 
Anak diseleksia sangat suka jika membaca buku bersama-sama. Tujuannya adalah agar anak menangkap banyak kosakata- kosakata baru. Sehingga anak akan merekam dalam memorinya. Anak juga di latih untuk membaca bersama orang tua. Orangtua secara tidak langsung mengajak anak untuk berlatih. Dengan begitu perlahanlahan kemampuan kognitif anak dapat meningkat. Orang tua perlu kerja sama dengan guru maupun pengajar di sekolahan. Pentingnya kerjasama antara pihak sekolah dengan orang tua. Hal ini dikarenakan anak tidak hanya mendapat pendidikan in formal saja , melainkan juga pendidikan formal. Peran guru sangat penting untuk membantu memecahkan permasalahan kognitif anak. Cara pengajaran guru juga sangat penting. Dengan kata lain, metode tang digunakan guru harus sesuai dengan kebutuhan anak. Jangan sampai metode yang salah justru akan membuat anak tambah bingung dan tambah sulit memahami pelajaran. Sehingga diperlukan guru yang kreatif pula dalam mengajar. Pembelajaran tidak monoton dan mampu membuat suasana menyenangkan bagi anak. Anak akan merasa senang bahkan menganggap gurunya sebagai teman sendri. Oleh sebab itu guru tidak hanya sebagai penyampai ilmu , melainkan sebagai sahabat dekat anak. Jangan sering membentak anak karena orang tua yang sering membentak anak akan berpengaruh terhadap perkembangan konitifnya. Hal ini disebabkan ketika anak dibentak sel- sel neuron yang ada pada otak akan terputus. Sehingga daya berfikir anak menjadi lambat bahkan susah memahami sesuatu, baik berhitung, membaca dan menulis(Loeziana, 2017).

Sedangkan menurut Arifin Mohammad menyarankan ada beberapa hal yang bisa dilakukan orang tua bagi anak penderita disleksia untuk meningkatkan kognitifnyaya itu : jangan memberi perkataan negatif seperti bodoh, pemalas, kurang cekatan, dan lainlain, jangan membanding - bandingkan dengan anak lain yang lebih pintar, jangan menekan anak, sehingga anak akan merasa takut gagal, jangan memaksa anak untuk membaca keras - keras dengan tujuan supaya bisa didengar orang lain, gunakan penanda atau alat bantu agar anak tahu alur bacanya, melatih keterampilan tanganya, seperti melempar bola dan melakukan permainan untuk motorik halusnya, berikan lingkungan yang kondusif serta guru yang profesional serta kompeten(Chairani, 2005). 
Ada beberapa penanganan terkait untuk meningkatkan kemampuan kognitif anak diseleksia diantaranya untuk mengembangkan bahasa dan bicara anak yang dilakukan dengan cara mendukung apa yang dilakukan anak, memancing anak untuk menceritakan apa yang sedang dilakukan, mislanya sedang membuat bentuk segitiga, persegi, meluangkan waktu untuk refresing kepada anak, membantu anak untuk mengamati apa yang dilihat, misalnya dalam permainaan, mengajari anak untuk memahami simbol - simbol serta bermain puzzle bersama. Kemudia dapat juga meningkatkan pengembangan fungsi auditif anak disleksia dengan cara memberikan kata kepada anak dengan huruf awal yang sama, mengetuk suatu objek kemudian anak disuruh untuk menebak bunyi benda itu serta membanntu anak untuk mengembangkan kebiasaan berlatih mendengarkan sesuatu pembicaraan kemudian mintalah si anak untuk mengulangi lagi(Hilmi \& Zaman, 2009).

Hal diatas bisa diterapkan orang tua dalam mendampingi anak disleksia. Penanganan yang tepat dapat membantu untuk anak disleksia dalam meningkatkan kemampuan kognitifnya. Sehingga anak yang disleksia bukan dianggap anak yang malas, anak yang bodoh, tatapi anak yang berbakat. Selain itu perlunya stmulasi- stimulasi orang tua terhadap anak penderita disleksia. Salah satunya adalah dengan stimulasi visual. Stimulasi visual adalah stimulasi yang menggunakan media visual (image atau perumpamaan). Media visual dapat memperlancar pemahaman dan memperkuat ingatan. Media visual juga memberikan hubungan antara isi materi dengan keadaan nyata. Stimulasi visual dilakukan dengan melihat objek, kemudian objek itu dimasukan ke ingatan.

Menurut Jolicoeur, ukuran bentuk obyek akan mempengaruhi visualisasi dalam ingatan. Hal ini mempengaruhi perbedaan rangsangan yang masuk berdasarkan penglihatan mata dengan sudut pandang terhadap ukuran yang diterima. penggunaan media visual harus mempertimbangkan hal- hal sebagai berikut : media visual dibuat sederhana misalnya menggunakan gambar garis, media visual digunakan untuk menekankan kata yang ada di teks, dapat menggunakan grafik untuk menggambarkan keseluruhan materi, melibatkan pendengar untuk mengingat daya ingat, menggunakan gambar untuk membedakan konsep serta menggunakan visual yang untuk mengkomunikasikan gagasan khusus jika jumlah objek dalam visual yang dimaksud benar(Kawuryan \& Raharjo, 2012). 
Selain dari orang tua, guru atau pendidik juga mempunyai tanggung jawab terhadap anak disleksi. Hal ini dikarenakan tidak semua pengetahuan guru bisa memahami perkembangan anak disleksia,maka diperlukan guru yang memang kompeten dan profesional untuk menangani anak disleksia. Pengalaman guru yang sudah penangani anak disleksia tentunya berbeda dengan guru- guru baru atau guru pra jabatan. Pengetahuan guru yang menjabat secara signifikan lebih baik daripada guru pra-jabatan dalam skala penuh dan sub-skala masing-masing. Namun, kurangnya informasi lebih tinggi untuk guru pra-jabatan. Tahun-tahun pengalaman mengajar, kemanjuran diri, dan pengalaman langsung dengan anak yang didiagnosis disleksia, berkorelasi positif dengan pengetahuan(Echegaray-Bengoa \& Soriano-Ferrer, 2016).

Bahwa pengetahuan guru dalam jabatan secara signifikan lebih baik daripada guru pra-jabatan secara penuh skala dan sub-skala masing-masing. Namun, kurangnya informasi lebih tinggi untuk guru pra-jabatan. Tahun-tahun pengalaman mengajar, kemanjuran diri, dan pengalaman langsung dengan seorang anak yang didiagnosis dengan disleksia, berkorelasi positif dengan pengetahuan.

Kemudian perlunya dilakukan metode atau strategi yang tepat pada anak disleksia, sehingga dapat meningkatkan kemampuan kognitifnya serta membaca dan menulis. Strategi pembelajaran untuk meningkatkan perkembangan kognitif bagi anak disleksia menurut Munawir adalah menggunakan metode sebagai berikut:

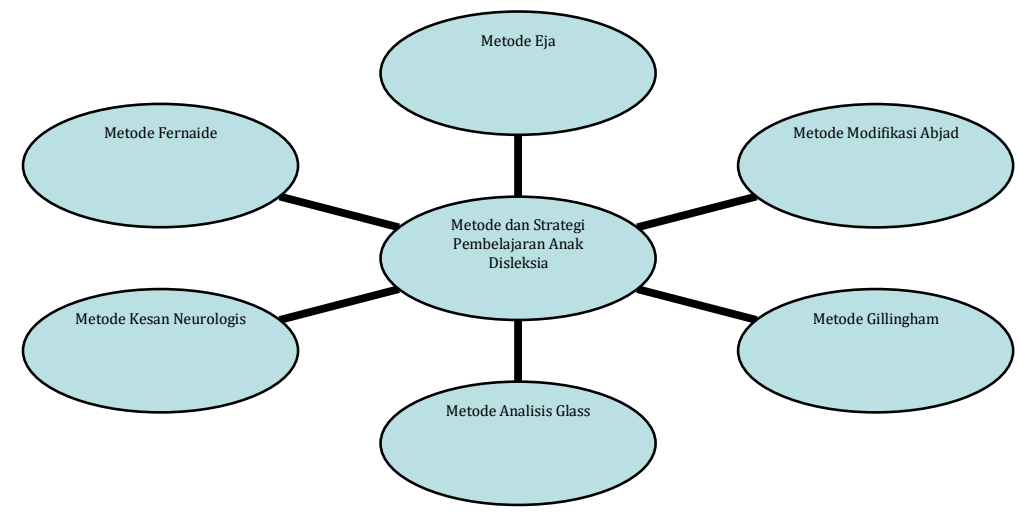

Sumber : Munawir 
Metode Eja mengajarkan cara membaca dengan teknik penggabungan huruf dan bunyi. Setelah anak menguasai huruf vokal dan konsonan kemudian belajar membaca dengan menggabungkan bunyi dari suku kata menjadi kata. Metode fernaide adalah metode pengajaran membaca multisensoris atau metode VAKT (visual, auditory, kinesthetic, and tactile). Metode ini menggunakan materi bacaan (cerita) dari kata- kata. Ada empat tahapan dalam metode fernaide, yaitu: (1) Anak memilih kata yang akan dipelajari kemudian guru akan menuliskan dipapan tulis/kertas dengan ukuran huruf yang besar kemudian anak diminta untuk menelusuri huruf itu menggunakan jarinya. Pada saat menelusuri huruf itu pasti anak melihat huruf/tulisan itu (visual), lalu mengucapkan dengan keras (auditory), kemudian cara ini dilakukan berulang- ulang supaya anak akan mengenali suaranya sendiri. Setelah itu anak diminta untuk menulis huruf tersebut. (2) Anak hanya melihat kata baru yang ditulis guru, kemudian mengucapkan dan menyalin tulisannya. (3) Guru tidak lagi menulis kata, tetapi anak diajarkan membaca huruf yang sudah ada di buku. Lalu anak ditugaskan mengucapkan dan menyalin. (4) Anak sudah mampu mengingat dan mengenal kata- kata baru dengan membandingkan kata yang sudah dipelajarinya.

Metode gillingham merupakan metode yang lebih terstruktur dan lebih mengarah pada penggabungan huruf dan bunyi. Metode ini diajarkan secara multisensori menggunakan kartu huruf dengan warna yang berbeda. Misalnya huruf konsonan warnanya hitam dan huruf vokal warna putih. Secara umum, deskripsi metode Gillingham adalah sebagai berikut: menggunakan kartu huruf yang ditujukan kepada anak. Anak diminta untuk mengulangi berkali- kali, lalu guru mengucapkan lagi huruf tersebut. Anak mengulangi lagi dan guru menanyakan" apa bunyi huruf ini ?". Guru langsung mengucapkan bunyi huruf dan bertanya " huruf apakah yang menghasilkan bunyi ini?”. Guru menuliskan huruf pelan - pelan dan menjelaskan bentuknya. Lalu anak menelusuri huruf itu dengan jarinya, menyalinnya, menuliskan di udara dan menyalinnya tanpa melihat contoh. Serta terdapat metode modifikasi abjad yang digunakan untuk anak yang membacanya tidak selalu konsisten. Metode ini mencoba menciptakan abjad baru sehingga ada terkaitan satu antara huruf dan bunyi. Sehingga ejaan yang tidak beraturan akan berubah. Misalnya kata"phone" dapat ditulis "fon". Ada lagi yang menimbulkan kesulitan misalnya huruf "o" (pohon). 
Metode kesan neurologis yang terdiri dari kegiatan membaca bersama secara cepat antara guru dan siswa. Tujuannya anak dapat mendengar suaranya sendiri dan suara orang lain yang membacanya sama. Kelebihan metode ini yaitu kemajuan dalam berekspres lisan, kelancaran membaca dan meningkatkan rasa percaya diri. Serta yang terakhir adalah metode analisis glass yang mana metode ini adalah metode pembelajaran melalui pemecahan sandi kelompok huruf dalam kata. Dalam metode ini proses pemecahan sandi dan membaca adalah kegiatan yang berbeda. Kamudian pemecahan sandi mendahului membaca. Pemecahan sandi yang dimaksud adalah penentuan bunyi yang tertulis secara tepat. Oleh karena itu, jika anak tidak mampu melakukan pecahan sandi maka anak akan sulit untuk membaca. Langkah melakukan metode ini yaitu: (1) mengidentifikasi seluruh kata dan bunyi kelompok huruf, (2) mengucapkan bunyi kelompok huruf, (3) menyajikan bunyi dan kelompok huruf kepada anak dan meminta untuk mengucapkannya, dan (4) guru mengambil beberapa huruf pada kata yang sudah tertulis kemudian anak meminta untuk mengucapkan kelompok huruf yang tersisa(Setiadi, 2015).

6. Analisis Perkembangan Anak Disleksia

Pelaksanaan praktik melibatkan anak kelompok TK B Di TK Bunga Harapan Ngaliyan. Subyek yang di teliti bernama Rasya Ramadhani. Lahir di Semarang pada tanggal 23 Juli 2014. Anak tersebut mengalami kesulitan dalam membedakan huruf " $S$ " dan " $Z$ ", dan huruf "b" dan "d". Dalam membedakan huruf "s" dan " $z$ " dan huruf "b" dan "d", rasya selalu mengalami kebingungan. Begitu pula ketika disuruh untuk menulis huruf tersebut. Hal ini disebabkan rasya belum terbiasa menulis kata yang melibatkan huruf. Contohnya ketika diminta untuk menulis namanya sendiri. Rasya kebingungan ketika menulis huruf "S"nya. Dan selalu terbalik menjadi huruf " Z". Sehingga namanya Rasya menjadi Razya. Instruksi kedua diminta untuk mengulang hasilnya sama yaitu menulis Ramadhani dan huruf "d" nya terbalik dengan huruf " $b$ ". Ketika ditanya mana yang disebut huruf " $b$ " Rasya menunjuk hurufnya" d". Ketika diminta untuk menulis, anak masih kebingungan, bahkan pernah menulisnya kebalik. Misalnya Rasya, menulisnya menjadi aysar, atau menulis hurufnya dari kanak ke kiri. Anak ini juga masih kebingungan untuk membaca, masih sulit memahami kata-kata yang tersusun. Anak secara motorik halusnya juga masih belum kuat. Perlu diberi stimulus secara terus-menerus agar motoriknya kuat. 
Dalam mengatasi gangguan terhadap Rasya, guru mendampingi dan melatih menggunakan metode gilinggam dengan multisensori menggunakan kartu huruf dengan warna yang berbeda. Cara ini diterapkan dengan memegang tangan anak ketika menulis huruf " $\mathrm{S}$ " dan "z" , huruf" b" dan "d". Guru langsung mengucapkan bunyi huruf tersebut dan menuliskan huruf perlahan-lahan dengan menjelaskan bentuknya. Misalnya ,"ini huruf "s" seperti sungai, anak menelusuri huruf dengan jarinya, mempraktekkan menuliskan di udara dilanjutkan menyalin dalam kertas tanpa melihat contoh. Metode gilinggam dengan multisensori dipraktikkan kepada Rasya, tahap awal anak belum menunjukkan perubahan, setelah dicoba beberapa kali terlihat ada perubahan yang signifikan terhadap perkembangan rasya dengan hambatan disleksia. Guru tetap memberi contoh di kertas lain dalam menulis hurufnya, dicoba berulang- ulang hingga berhasil, ketika anak diberikan pertanyaan oleh guru "huruf "s" itu seperti apa?", hanya bilang" huruf "s" itu seperti "sungai", dan rasya sudah bisa menulis hurufnya, sehingga guru tidak perlu mencontohkan.

\section{KESIMPULAN}

Disleksia adalah suatu kelainan pada otak yang ditandai dengan kesulitan mengenali kata- kata baik membaca, memahami simbol serta membedakan huruf sehingga menghambat perkembangan kognitif pada anak. Faktor penyebab anak mengalami disleksia ada tiga, yaitu faktor pendidikan, psikologis, dan biologis. Tetapi faktor yang paling utama adalah kelainan otak. Adanya konektivitas yang buruk pada bagian fungsi otak, yaitu pada daerah brocas, lobus frontal dan korte. Strategi pembelajaran untuk meningkatkan perkembangan kognitif bagi anak disleksia yaitu menggunakan metode eja, metode fernaide, metode gillingham, metode modifikasi abjad, metode kesan neurologis, metode analisis glass. 
Metode gilinggam sebagai rujukan penanganan masalah perkembangan anak disleksia, metode gilinggam merupakan penggabungan huruf dan bunyi, diajarkan secara multisensori menggunakan kartu huruf dengan warna yang berbeda. Misalnya huruf konsonan warnanya hitam dan huruf vokal warna putih. Keterlibatan orang tua dan guru sangat berperan dalam memberikan stimulus serta pendampingan terhadap anak. Penanganan yang tepat dan tidak terlambat dapat membantu mengatasi masalah anak disleksia dalam meningkatkan kemampuan kognitifnya.

\section{DAFTAR PUSTAKA}

Chairani, N. (2005). Biarkan Anak Berbicara. Jakarta: Republika.

Echegaray-Bengoa, J., \& Soriano-Ferrer, M. (2016). Conocimientos de los maestros acerca de la dislexia del desarrollo: implicaciones educativas. Aula Abierta, 44(2).

Hermijanto, O. B., \& Valentina, V. (2016). Disleksia Bukan Bodoh,Bukan Malas, Tetapi Berbakat. Jakarta: PT. Gramedia Pustaka Utama.

Hilmi, D. R., \& Zaman, S. (2009). Permainan Meningkatkan Inteligensi Anak. Jakarta: Visimedia.

ADDIN Mendeley Bibliography CSL_BIBLIOGRAPHY Hidayah, R. (2013). Aplikasi teori fonologi pada penanganan anak berkesulitan membaca. 10 .

Ibda, F. (2015). Perkembangan Kognitif : Teori Jean Piaget. 3.

Inkofar, J. (2017). Perancangan aplikasi sistem pakar dengan menggunakan metode. 1(1), 12-17.

Irdamurni, Kasiyatil, Zulmiyetri, J. T. (2018). Meningkatkan Kemampuan Guru Pada Pembelajaran Membaca Anak Disleksia. Jurnal Pendidikan Kebutuhan Khusus, Volume 2(No 2), Hlm 29.

Kawuryan, F., \& Raharjo, T. (2012). Pengaruh Stimulasi Visual Untuk Meningkatkan Kemampuan Membaca Pada Anak Disleksia. Jurnal Psikologi Pitutur, Volume 1(No 1), Hlm 12-13. 
León, A. M., Bravo, C. B., \& Fernández, A. R. (2017). Review of Android and iOS Tablet Apps in Spanish to Improve Reading and Writing skills of Children with Dyslexia. Procedia - Social and Behavioral Sciences, 237.

Lidwina, S. (2012). Disleksia Berpengaruh Pada Kemampuan Membaca

Dan Menulis. Jurnal STIE Semarang, Volume 4(No 3), Hlm 13-16.

Loeziana. (2017). Urgensi mengenal ciri disleksia. Volume 3(No 2), Hlm 56.

Ozila Sandriani, Ganda Sumekar, Y. A. (2013). Efektivitas Teknik Jarikubaca Dalam Meningkatkan Kemampuan Membaca Kata Bagi Anak Disleksia. Jurnal Ilmiah Pendidikan Khusus, Volume 2(No 3), HIm 433.

Pratiwi, I., Hapsari, F. D., \& Argo, C. B. (2015). Pembelajaran Teknik Puzzle Huruf Untuk Meningkatkan Keterampilan Membaca Anak Disleksia. Universitas PGRI Yogyakarta, 143.

Setiadi, H. W. (2015). Strategi Pembelajaran Untuk Meningkatkan

Keterampilan Baca Tulis Siswa. Universitas PGRI Yogyakarta, HIm 91-95.

Sri Respati Andamari, U. A. (2017). Implementasi Terapi Berbasis Aplikasi Android dan Terapi Verbal untuk Meningkatkan Kemampuan Membaca pada Anak dengan Gejala Disleksia. Jurnal Psikologi, Volume 2(No 1), 18.

Tammasse. (2017). Mengatasi Kesulitan Belajar Disleksia(Studi Neuropsikolinguistik). Fakultas Ilmu Budaya, Universitas Hasanuddin, Hlm 5.

Tri Wulan Sari, Anna Vitara, M. P. P. (2015). Meningkatkan Motivasi Belajar Anak Disleksia Untuk Mengurangi Kesulitan Belajar Membaca Permulaan. Universitas PGRI Yogyakarta, 149.

Ubaidullah, N. H., \& Zaman, H. B. (2011). Aspek-aspek Pedagogi dalam Perisian Kursus Multimedia ( D-Matematika ) bagi Kanakkanak Disleksia Pengenalan Disleksia merupakan kesulitan pembelajaran yang dihadapi oleh sama ada golongan. 3(2), 42-58.

Varia Nihayatus Saadah, N. H. (2013). Pengaruh Permainan Srabble Terhadap Peningkatan Kemampuan Membaca Anak Disleksia. Jurnal Fakultas Psikologi, Volume 1(No 1), 41. 